\title{
The Effect of Discovery Learning Model on Students' Ability to Write Fantasy Stories
}

\author{
Nia Noviani \\ SMP Negeri 1 Prabumulih \\ nianoviani999@gmail.com \\ Missriani \\ Universitas PGRI Palembang \\ missriani@yahoo.com \\ Dessy Wardiyah \\ Universitas PGRI Palembang \\ dessywardiyah77@gmail.com
}

\begin{abstract}
This study aims to determine whether there is an effect of the Discovery Learning model on improving the ability to write fantasy stories of seventh grade students of SMP Negeri 1 Prabumulih. This research is an experimental research (Experimental Research). Data collection techniques using observation, tests and documentation. The data analysis technique used independent samples t test. The results stated that 1) The ability to write fantasy stories of seventh grade students of SMP Negeri 1 Prabumulih after using the Discovery Learning learning model was in the high category. Then the ability to write fantasy stories using conventional learning models is in the high enough category; 2) There is an effect of the Discovery Learning learning model on the ability to write fantasy stories of VII grade students of SMP Negeri 1 Prabumulih based on the average value of the ability to write fantasy stories of seventh grade students of SMP Negeri 1 Prabumulih after using the Discovery Learning learning model which is higher than the ability to write fantasy stories of students which uses conventional amounting to 90.00. Therefore, it can be that the Ho3 hypothesis is accepted, meaning that there is an influence of the Discovery Learning Model on the ability to write fantasy stories of seventh grade students of SMP Negeri 1 Prabumulih.
\end{abstract}

Keywords: Learning model; discovery learning; students' ability; fantasy stories

\section{A. Introduction}

National education, as one of the sectors of national development in an effort to educate the nation, has a vision of the realization of the education system as a strong and authoritative social institution to empower all Indonesian citizens to develop into qualified human beings so that they are able to answer the challenges of the ever-changing times.

In the Government Regulation of the Republic of Indonesia Number 19 of 2005 concerning National Education Standards; and Government Regulation Number 32 of 2013 concerning Amendments to Government Regulation Number 19 of 2005 concerning National Education Standards.

In those two regulations, it is stated that the National Education Standards are the minimum criteria for the education system in all jurisdictions of the Republic of Indonesia. The National Education Standard aims to guarantee the quality of national education in order to educate the nation and shape the character and civilization of the nation with dignity. The National Education Standards include eight standards, one of which is the Process Standard. 
Process Standards are criteria regarding the implementation of learning in one education unit to achieve Graduate Competency Standards.

In the 2013 curriculum, students are no longer objects of education, but instead become subjects by participating in developing existing themes and materials. With this change, of course the various standards in the component of education will change. Thus, the overall success of learning depends on the skills of teachers in designing learning materials.

As the results of research conducted by Utami (2018) which showed that there is an effect of teaching skills on learning motivation. Then, Ningsih, Patampang \& Hamid (2018) with research results which stated that there is an influence between teacher teaching skills on student learning outcomes.

Therefore, teachers are required to be creative in preparing teaching materials. Learning materials are designed as optimally as possible to help students achieve these goals, the teacher must pay attention to matters relating to the selection of learning materials, such as the type, scope, sequence, and treatment of these materials. Related to this, if the teacher has the expertise in compiling the learning material, it will help the potential emergence and increase students' ability. The success of learning as a whole depends on the teacher in designing the course of learning that is interesting and fun. This requires teachers to be creative in making innovative teaching materials. Teaching materials are all materials (either information, tools, or texts) that are arranged systematically, displaying a complete figure of the competencies that students will master in the learning process with the aim of planning and studying the implementation of learning (Prastowo, 2015: 17). Teaching materials are designed optimally to help students achieve their learning goals.

Indonesian language learning materials include language and literary skills covering four aspects of listening, speaking, reading, and writing skills. Writing is one of the language skills needed to improve the quality of learning (Rahmawati, et al. 2019). However, writing can be done by reading a book because by reading, the students or people can write (Martina, et al. 2020; Wibowo, et al. 2020; Martina, et al. 2020; Febriani, et al. 2020)

Having mastery of writing skills, it is expected that students can express the ideas, thoughts, and feelings they have after undergoing the learning process in various types of writing, both fiction and non-fiction. Tarigan (2013: 15) stated that writing is defined as an activity to express ideas using written language as a medium of delivery. By writing, students are able to construct various knowledge they have in writing, whether in the form of essays, articles, scientific reports, news, short stories, poetry and so on. The expected goal in learning to write is that students are able to understand and be able to express some of the things they catch, ideas, opinions, messages and feelings in written form.

The aspect of writing skills is a skill that cannot be separated from the role of other skill aspects, that is listening, speaking, and reading. A person can write whatever is on his/her mind through experiences that may have previously been heard and from his/her reading experience. This makes the writing aspect closely related to other aspects of language skills and makes writing skills a high-level linguistic skill. The role of writing skills in life is the basis for the development of the text-based 2013 curriculum. When compared to the previous curriculum, the 2013 curriculum emphasizes the students' ability to recognize and create various types of literary and non-literary texts.

Therefore, writing skills are very important to improve. There is the need to develop students' potential to be skilled at writing. Writing is a productive and expressive activity (Tarigan, 2013: 3). Not only productively creating writing and expressing feelings, writing skills involve creativity and thinking. By writing, a person will be able to voice whatever ideas, event reports, community problems, economic, social, cultural, and political conditions want. Writing is a complex activity, because by writing, a person is required to organize their thoughts and feelings through writing. 
Learning literature in the context of the 2013 revised edition of the curriculum is considered interesting to be researched, coupled with the role of knowledge competencies and skills competencies that are prioritized in the 2013 curriculum, making literary learning not only know theoretically but students are given the opportunity to create their own work. Literary creative education tries to teach students to be willing and able to write literary works. One of the basic writing competencies contained in the Indonesian junior high school curriculum is writing fantasy story texts in accordance with the structure and rules of language. Fantasy story text is a prose fiction story whose contents tell things beyond human reason and are formed from the author's fantasy.

A fantasy story is a development of a narrative text that can be turned into a fictional story. Fantasy stories are one of the most popular literary genres nowadays. Not only are the stories absurd, but the characters with unique characteristics created in fantasy stories are the reason why many people love them. In writing fantasy story texts, orientation is aimed at presenting various possible interpretations of life, telling something that is not what happens on this earth, but as imagined or imagined to happen. In addition, it takes the writer's imagination or delusion. This is in accordance with the character of students aged seven to eleven years, who are in the intellectual development phase of the concrete operational stage. At this time, students begin to be able to develop their imagination to the past and future (Zulela, 2013: 53).

By learning to write fiction stories, it becomes the first step for students to find out how to develop their imagination and put it in written language in the form of a fantasy story text. Learning to write fantasy story texts is very important, but based on reality, most students experience problems in its application. One school that experienced difficulties in learning to write fantasy story texts was a seventh grade student at SMP Negeri 1 Prabumulih. Efforts to improve students' writing skills, especially in fantasy story text writing material, are not easy. There are obstacles encountered in the field so that the expected results have not been achieved. Based on the results of the preliminary study, basically the learning activities to write fantasy story texts tend to be conveyed unattractive and less creative. The teachers only use textbook teaching materials without using varied learning models or the unsuitable approach applied by the teacher in the teaching and learning process.

Based on observations that the researcher has made in class VII B of SMP Negeri 1 Prabumulih, it showed that some students experienced problems in producing fantasy story texts. There are several things that can be the contributing factors. These factors include the learning process that occurs in class which is still monotonous. In this case, the teacher is less varied in choosing learning methods so that students feel bored, unmotivated and not interested in taking part in learning to write fantasy story texts. Such a learning process does not get maximum results because the teacher does not provide guidance in writing fantasy story texts.

Another problem encountered by the researcher is learning to write creative text of fantasy stories is often considered unattractive by some students. Student interest in writing is very low, because many students think that writing is very difficult. Students feel reluctant to learn to write, especially writing fantasy story texts because they experience many difficulties. These difficulties include difficulties in determining the theme of the story, difficulties in getting ideas and developing them into a story. In addition, students also feel bored with the theoretical explanation given by the teacher so that it affects students' motivation in writing. This lack of motivation and interest greatly affects the development of students' creativity and imagination in writing fantasy story texts.

The lack of student interest in learning can be seen from the attitude of students who do not respect the learning process, the number of students who are still chatting when the teacher starts learning, drowsiness during the teaching and learning process, there are still 
many students who do not dare to ask questions or answer questions raised by the teacher, in learning they still rely on instructions from the teacher to study a material, students are less active in participating in learning, and students who lack a creative attitude in expressing ideas or creating a work.

Discovery Learning Model. Discovery is an activity designed in such a way that students can discover concepts and principles through their own mental processes. Discovery occurs when students in their mental processes (observing, classifying, making guesses, explaining, and drawing conclusions) find several concepts or principles (Rahman and Maarif, 2014: 40). According to Sund (in Roestiyah, 2008: 20) discovery model is a mental process experienced by students so that students are able to assimilate a concept or principle. Mental processes, that is observing, digesting, understanding, classifying, making assumptions, explaining, measuring, making conclusions, and so on.

In line with that opinion, Hosnan (2014: 282) also stated that the discovery model is a model for developing active student learning by discovering on their own, and investigating on their own so that the results obtained will be loyal and durable in students' memories. In discovery learning, students are encouraged to learn largely through their own active engagement with concepts and principles, then the teacher encourages students to have experiences and conduct experiments that allow them to discover these principles (Wilcox in Hosnan, 2014).

\section{B. Research Methodology}

This research is an Experimental Research. Experimental research is research that is used to find differences in certain treatments against others under controlled conditions. The controlled condition referred to is that the results of the study are converted into numbers, for analysis used by statistical analysis (Sugiyono, 2011). The data collection techniques used observation, tests and documentations. The research instrument consisted of 1) Field Note; 2) Observation Sheet; 3) Test; 4) Documentation Check List. The data analysis technique used independent samples $t$ test to test the effect of each learning model and to compare which learning model was more effective. Quantitative data processing in this study used SPSS 22.00 For Windows.

\section{Results and Discussion}

\section{Results}

\section{Description of Ability to Write Fantasy Stories Using Discovery Learning Model}

The test for the ability to write fantasy stories of students on this variable was carried out four times in class VII A of SMP Negeri 1 Prabumulih starting from December 2 to December 16, 2019. At the first and second meetings, the learning process was carried out using conventional learning models for 2 meetings, that is on December 2, 2019 and December 5, 2019. At the first meeting, the learning process was filled with an explanation of the material for writing fantasy stories and ended by concluding the material that had been discussed, and providing reinforcement for the conclusions formulated by students. At the second meeting, which was on December 5, 2019, the learning process was the same as the first meeting, however the researcher had prepared an observation sheet to assess student activeness in the learning process and the researcher gave a test to the student at the end of the lesson.

Then in the learning process using the Discovery Learning model, it was carried out with 2 meetings starting on December 16, 2019 to December 19, 2019. At the first meeting, which was Monday, December 19, 2019, the learning process was filled with learning material to write fantasy stories with a discussion process and ended with questions and 
answers and the teacher provided reinforcement for the conclusions formulated by students. At the second meeting, which was on December 19, 2019, the learning process was the same as the first meeting, however the researcher had prepared an observation sheet to assess student activeness in the learning process and the researcher gave a test to the student at the end of the lesson. From the results of the tests conducted by the researcher, the total score of the ability to write fantasy stories using conventional models (before) and by using the Discovery Learning model (after) in class VII A students of SMP Negeri 1 Prabumulih was obtained as follows.

\section{The Results of the Test of the Ability to Write Fantasy Stories Using Conventional Learning Model}

Based on quantitative descriptive, the total score obtained by grade VII students of SMP Negeri 1 Prabumulih through the test of the ability to write fantasy stories after using conventional based on the results of data analysis showed that the highest score obtained by conventional students is 90 while the lowest score is 75 with a mean of 81.8 , mode (the most frequent value) is 85 , the variant value is 28.4 , the standard deviation is 5.3 . The results of the analysis of the frequency distribution of the ability to write fantasy stories using conventional learning model noted that there are 18 of the 30 students or $60 \%$ with very high value criteria, 11 or $36.7 \%$ of students with scores are in the high category and 1 or $3.3 \%$ of students are in the high enough category. The total score obtained was 2455 and the ideal score was 3000 with the effectiveness criteria of $82 \%$, between $68.01 \%-84 \%$, this is included in the high criteria. Thus, it can be argued that the ability to write fantasy stories using conventional learning models is in the high category. The criteria for the ability to write fantasy stories using conventional learning models can be seen in the following figure.

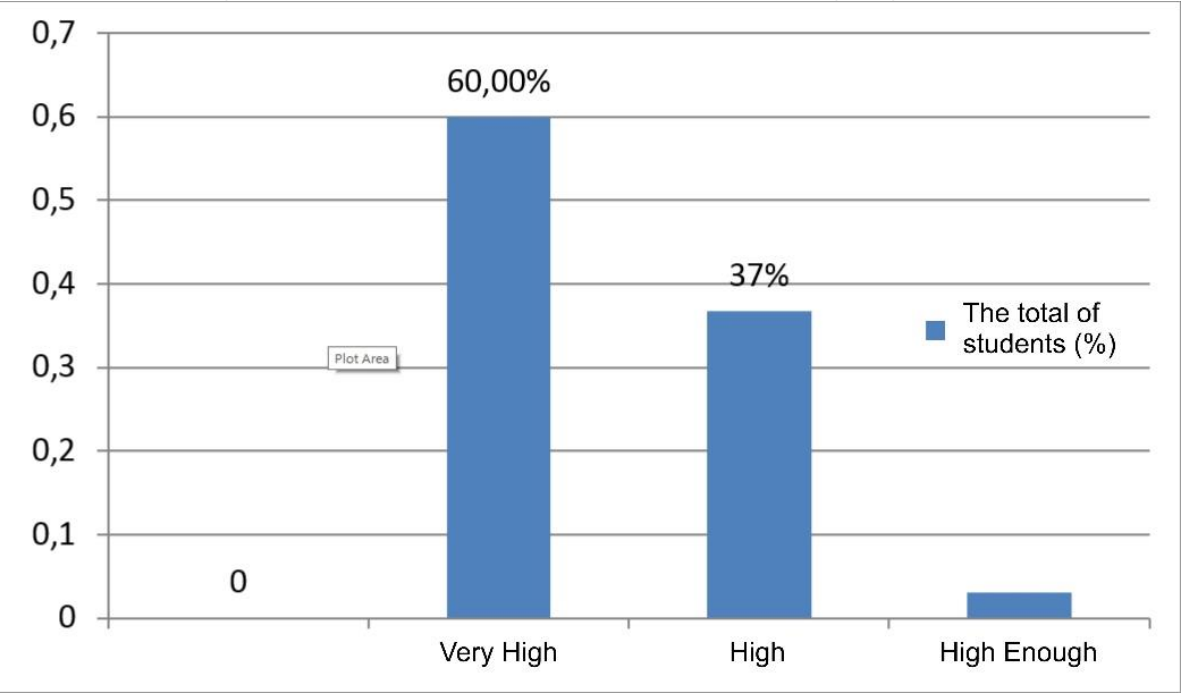

Figure 1 Criteria for Ability to Write Fantasy Stories Using Conventional Learning Model

Based on the observation sheet carried out by the researcher during the learning process using the conventional which consists of several indicators of activity, that is 1) the ability of students to ask questions that they do not understand, 2) answer questions in the discussion 3) express opinions, 4) the ability to conclude lessons, and 5) the ability of students to cooperate with their friends. The results of the observation of students' activity during the learning process using conventional learning model showed that there were 6 students who actively asked questions or $20 \%$, the second meeting increased to 7 students or $23.3 \%$, for students who were able to answer at the first meeting as many as 5 students or $16.5 \%$, the second meeting did not increase, still only 5 students or $16.5 \%$, students who were able to express opinions in the discussion at the first meeting were 6 students or $20 \%$, at 
the second meeting increased to 8 people or by $26.6 \%$. For students who were active in conducting discussions in the learning process of the first meeting as many as 13 students or $43.3 \%$, at the second meeting as many as 15 students $50 \%$, Students who are able to become expert or are able to master the sub material given at the first meeting are 4 students or $13.3 \%$, at the second meeting increased by 6 students or $33.3 \%$, students who are able to work together or help each other with their friends in the learning process at the first meeting there were 13 students or $43.3 \%$, at the second meeting it increased to 15 students or $50 \%$, students who were able to conclude the material were only 4 people $13.3 \%$, at the second meeting it did not increase, still only 4 people $13.3 \%$. Every time starting the learning process, apperception is carried out by asking a number of questions regarding the subject matter that has been studied. At the first meeting there were 5 students or $16.6 \%$ who could answer, at the second meeting it increased to 6 people or $29 \%$. Based on the observation data that has been described above, it shows that by using conventional learning, enthusiasm, activeness, the ability to work together and the analytical skills and critical power of students in learning do not always increase at every meeting.

\section{The Results of the Test of the Ability to Write Fantasy Stories Using Discovery Learning Model}

The results of the students' ability to write fantasy stories using the Discovery Learning learning model were in the very high category. The criteria for the ability to write fantasy stories using the Discovery Learning model can be seen in the following figure.

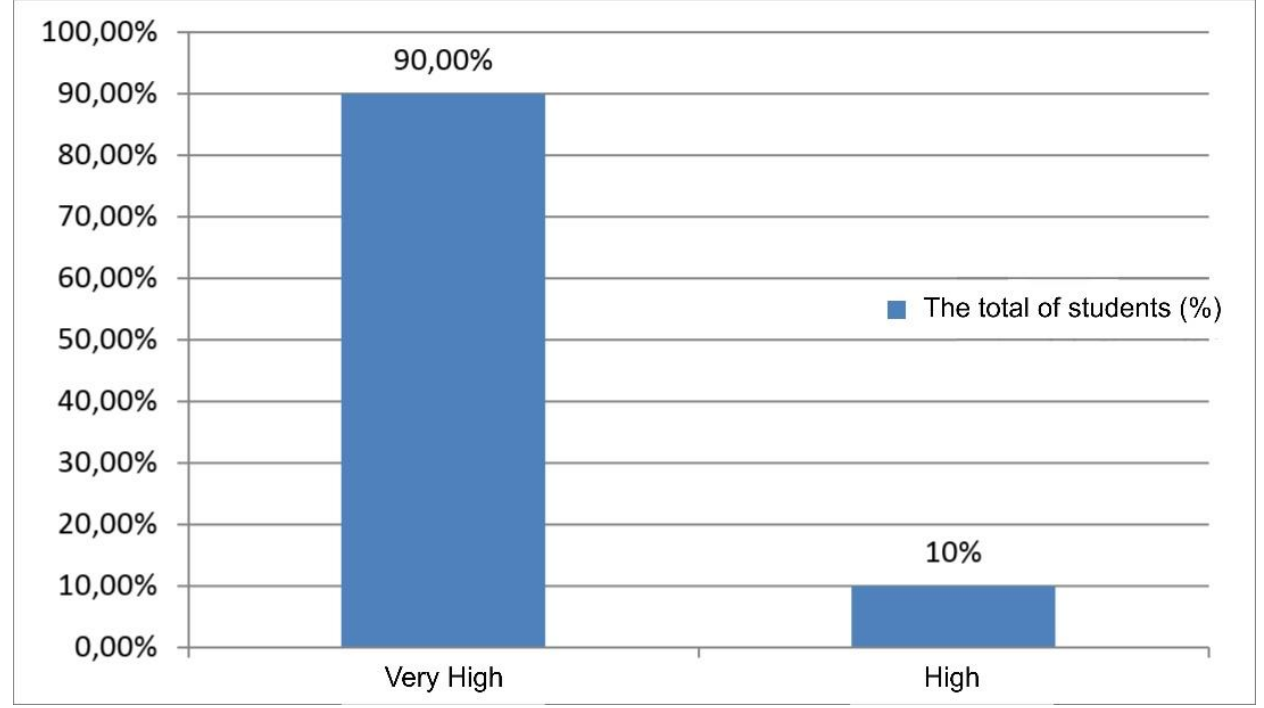

Figure 1 Criteria for Ability to Write Fantasy Stories

Using Discovery Learning Model

The results of the frequency distribution analysis above are supported by the results of observations based on the observation sheet conducted by the researcher. Observation of student participation during the learning process useing the Discovery Learning model which consists of several indicators of activity, namely, 1) the ability of students to ask questions that they do not understand, 2) to answer questions in the discussion 3) express opinions, 4) ability to conclude lessons, and 5) the ability of students to cooperate with their friends.

The results of the analysis show that the active students during the learning process using the Discovery Learning learning model obtained 4 students who actively asked questions or $13.3 \%$, the second meeting increased to 9 students or $30 \%$. For students who were able to answer at the first meeting were 5 students or $16.5 \%$, the second meeting increased to 8 students or $26.6 \%$, Students who were able to express opinions in the 
discussion at the first meeting were 5 students or $16.6 \%$, at the second meeting were 9 people or $30 \%$. For students who were active in discussing the learning process at the first meeting were 13 students or $43.3 \%$, at the second meeting $60 \%$ were 18 students, students who were able to become experts or were able to master the sub material given at the first meeting as many as 4 students or $13.4 \%$, at the second meeting as many as 10 students or $33.3 \%$, students who could work together or help each other with their friends in the learning process, at the first meeting there were 16 students or $53.3 \%$, at the second meeting it increased to 21 students or $70 \%$, they were able to help each other or cooperate with their friends in the learning process, only 9 students or $30 \%$ were able to conclude the material, at the second meeting it increased to 20 people or $66.7 \%$. Every time starting the learning process, apperception is carried out by asking a number of questions regarding the subject matter that has been studied. At the first meeting there were 8 students or $16.5 \%$ who could answer, at the second meeting it increased to 10 people or $30 \%$.

Based on the observation data that has been described above, it shows that by learning using the Discovery Learning model, enthusiasm, activeness, the ability to work together and the analytical skills and critical power of students in learning always increase at every meeting.

\section{Hypothesis Testing}

The Effect of Discovery Learning Model on the Improvement of the Ability to Write Fantasy Stories in Seventh Grade of SMP Negeri 1 Prabumulih

The results of the students' fantasy story writing ability scores in a class using the Discovery Learning model and students' fantasy story writing abilities using conventional learning models can be seen in the following table.

Based on the results of the total score of the students, it can be analyzed the comparison between the Discovery Learning and conventional learning models on the improvement of the ability to write fantasy stories of seventh grade students of SMP Negeri 1 Prabumulih. From the results of the comparison test, it can be seen that from the results of the Independent Samples Test above, it can be obtained that the sig 2 tailed value is 0.00 less than 0.05 . Thus there is a difference in the value of the ability to write fantasy stories of class VII students of SMP Negeri 1 Prabumulih after using the Discovery Learning learning model with the value of the ability to write fantasy stories of conventional students. To find out whether the comparison of the ability to write fantasy stories of seventh grade students of SMP Negeri 1 Prabumulih who used the Discovery Learning model with the ability to write fantasy stories of seventh grade students of SMP Negeri 1 Prabumulih Conventional, it can be seen from the comparison of the average value of the two test results. The difference in the average value can be seen in the following Group Statistics table

Tabel 3. Group Statistics

\begin{tabular}{lccccc}
\hline & Class & $N$ & Mean & $\begin{array}{c}\text { Std. } \\
\text { Deviation }\end{array}$ & $\begin{array}{c}\text { Std. Error } \\
\text { Mean }\end{array}$ \\
\hline Value & $\begin{array}{c}\text { Discovery } \\
\text { Learning }\end{array}$ & 30 & 90.00 & 5.414 & .988 \\
Conventional & 30 & 81.83 & 5.331 & .973
\end{tabular}

Based on the table above, it can be seen that the average score of the ability to write fantasy stories of VII grade students of SMP Negeri 1 Prabumulih before using the Discovery Learning learning model is 90.00 , while the ability to write fantasy stories using conventional students is 81.83 . Thus it can be known that the average score of the ability to write fantasy stories of students of class VII SMP Negeri 1 Prabumulih after using the Discovery Learning model is higher than the ability to write fantasy stories using conventional students, which is 
90.00. Therefore, it can be argued that the Ho3 hypothesis is accepted, meaning that there is an influence of the Discovery Learning learning model on the ability to write fantasy stories of seventh grade students of SMP Negeri 1 Prabumulih.

\section{Discussion}

\section{Results of the Statistical Description Analysis of the Ability to Write Fantasy Stories of Seventh Grade Students of SMP Negeri 1 Prabumulih after using Conventional Model}

The results of quantitative descriptive analysis of the ability to write fantasy stories using conventional learning models obtained results from 30 students, there were 18 or $60 \%$ of students with very high score criteria, 11 or $36.7 \%$ of students with scores are in the high category and 1 or $3.3 \%$ of students are in the high enough category. The total score obtained is 2455 and the ideal score is 3000 with the effectiveness criteria of $82 \%$, between $68.01 \%$ $84 \%$, including the high criteria. Thus, it can be argued that the ability to write fantasy stories using conventional learning models is in the high category. Then based on the data from the observations it shows that by using conventional learning, enthusiasm, activeness, the ability to work together and the analytical skills and critical power of students in learning do not always increase at every meeting.

\section{Results of the Statistical Description Analysis of the Ability to Write Fantasy Stories of Seventh Grade Students of SMP Negeri 1 Prabumulih after using Discovery Learning Model}

Based on the statistical description analysis of the ability to write fantasy stories test of seventh grade students of SMP Negeri 1 Prabumulih after using the Discovery Learning learning model, The results obtained from 30 students were 27 or $90 \%$ of students with very high criteria and 3 or $10 \%$ of students with scores included in the high category. The total score obtained is 2700 and an ideal score of 3000 with the effectiveness criteria of $90 \%$ is between $84.01 \%-100 \%$, including the very high criteria.Thus, it can be argued that the ability to write fantasy stories using the Discovery Learning learning model is in the very high category. . Then from the results of observations made by the researcher using the observation sheet, it shows that by learning using the Discovery Learning model, enthusiasm, activeness, the ability to work together and the analytical skills and critical power of students in learning always increase at every meeting.

\section{The Effect of the Discovery Learning Model on the Improvement of the Ability to Write Fantasy Stories in VII Grade of SMP Negeri 1 Prabumulih}

Based on the results of the comparison test, it was obtained that the sig 2 tailed value was 0.00 , smaller than 0.05 . thus there is a difference in the value of the ability to write fantasy stories of class VII A students of SMP Negeri 1 Prabumulih after using the Discovery Learning learning model with the value of the ability to write fantasy stories of conventional students. The average value of the ability to write fantasy stories of students of class VII SMP Negeri 1 Prabumulih before using the Discovery Learning learning model was 90.00 while the ability to write fantasy stories using conventional students was 81.83 .

Thus it can be seen that the average score of the ability to write fantasy stories of students of class VII SMP Negeri 1 Prabumulih after using the Discovery Learning learning model is higher than the ability to write fantasy stories using conventional students, which is 90.00. Therefore, it can be argued that the Ho3 hypothesis is accepted, meaning that the Discovery Learning model is more effective than conventional to improve the ability to write 
fantasy stories of seventh grade students of SMP Negeri 1 Prabumulih.

Based on the research results above, it can be seen that conventional is still not effective compared to the Discovery Learning learning model in an effort to improve students' ability to write fantasy stories. This is because the conventional really requires students to be totally involved in learning activities. Therefore, it requires maximum readiness for students in carrying out the learning process using conventional.

Conventional model requires a readiness and a longer meeting process than the Discovery Learning model. A short meeting treatment still makes students awkward in asking questions, still hesitate in expressing opinions and answering questions and also still having problems working with fellow students. On average, students who were active in group discussions at the initial meeting were only students who had high academic abilities.

In addition, the ability to interpret and make learning conclusions is still lacking in the initial learning meeting. This is because students are still not confident when given full trust by the teacher to express their opinions. The deficiencies and disturbances experienced by students in carrying out the learning process using conventional models at all meetings (the first meeting and the second meeting) can be understood because during the previous lesson students have been accustomed to learning using conventional methods, which is learning that is done classically and one direction.

The advantages of the Discovery Learning model compared to conventional lies in the division of roles between teachers and students which is professional. This makes students do not need a long time to adapt to the learning model that makes students active in the learning process. Gradually increased. This can be seen from the results of observations where learning using the Discovery Learning model always increases at the second meeting. Meanwhile, conventional learning has not provided improvement in several indicators of student activity.

Based on the findings in this study, it can be concluded that the use of the Discovery Learning model as a success strategy can be used as an effective learning model to improve students' ability to write fantasy stories compared to conventional ones.

\section{Conclusion and Suggestion Conclusion}

Based on the results of the research and discussion described above, the following conclusions can be drawn.

1. The ability to write fantasy stories of seventh grade students of SMP Negeri 1 Prabumulih after using the Discovery Learning learning model is in the high category. Then the ability to write fantasy stories using conventional learning models is included in the high enough category.

2. There is an effect of the Discovery Learning model on the ability to write fantasy stories of seventh grade students of SMP Negeri 1 Prabumulih based on the average value of the ability to write fantasy stories of seventh grade students of SMP Negeri 1 Prabumulih after using the Discovery Learning learning model which is higher than the ability to write fantasy stories of students who use conventional which is equal to 90.00. Therefore, it can be argued that the Ho3 hypothesis is accepted, meaning that there is an influence of the Discovery Learning Model on the ability to write fantasy stories of seventh grade students of SMP Negeri 1 Prabumulih.

\section{Suggestions}

Based on the above conclusions, the following suggestions can be made.

1. It is hoped that the Principal of SMP Negeri 1 Prabumulih will be able to provide continuous training for teachers, especially Indonesian language teachers so that they have 
Jadila: Journal of Develowment and Innovation in Language and Literature Education

Publisher: Yayasan Karinosseff Muda Indonesia
E-ISSN: 2723-6900

Volume 1 Number 22020

Page : $150-160$

extensive knowledge regarding the use of effective learning models to improve the quality of learning.

2. Teachers of SMP Negeri 1 Prabumulih, especially Indonesian language teachers, are expected to be able to use the Discovery Learning model which is considered effective to improve the writing ability of Grade VII students of SMP Negeri 1 Prabumulih.

3. To the next researchers, in order to be able to examine more deeply the problems that teachers encounter in conventional use that are less effective than the Discovery Learning learning model.

\section{References}

Adeani, I. S., Febriani, R. B., Syafryadin, S., Mangana, A. V., Kurniawan, E., Ananda, J., \& Maryam, S. Using GIBBS reflective cycle in making reflections of literary analysis. Indonesian EFL Journal (IEFLJ). 6(2), 139-148.

Dhillon, B. P. S., Herman, H., \& Syafryadin, S. (2020). The effect of skimming method to improve students' ability in reading comprehension on narrative text. Linguists: Journal Of Linguistics and Language Teaching, 6(1), 77-88.

Febriani, R. B. Satinem., Nurnaningsih., Haryani., Syafryadin, Noermanzah.(2020). Conveying an author's intention to efl readers: The meaning of "The Road Not Taken" by Robert Frost. International Journal of Innovation, Creativity and Change (IJICC), 13(4), 172.

Hosnan. (2014). Pendekatan saintifik dan konseptual dalam pembelajaran abad 21. Bogor: Ghalia Indonesia.

Martina, F., Syafryadin, S., \& Utama, J. A. (2020). The practice of extensive reading among EFL learners in tertiary level. Yavana Bhasha: Journal of English Language Education, 3(2), 56-72.

Martina, F., Syafryadin, S., Rakhmanina, L., \& Juwita, S. (2020). The effect of time constraint on student reading comprehension test performance in narrative text. Journal of Languages and Language Teaching, 8(3), 323-329.

Ningsih,Y, S, Patampang \& AHamid, A. (2018). Pengaruh keterampilan mengajar guru terhadap hasil belajar siswa pada mata pelajaran geografi SMA Negeri 1 Lembo Kabupaten Morowali Utara. Jurnal Elektronik GeoTadulako Online. I6(1, 31-41.

Peraturan Pemerintah (PP) Republik Indonesia Nomor 19 tahun 2005 Tentang Standar Nasional Pendidikan (SNP)

Prastowo, A. (2015). Panduan kreatif membuat bahan ajar inovatif. Yogyakarta: Diva Press.

Rahman, R dan Maarif, S. (2014). Pengaruh penggunaaan metode Discovery terhadap kemampuan analogi matematis siswa SMK Al-Ikhsan Pamarican, Kabupaten Ciamis, Jawa Barat. INFINITY Jurnal Ilmiah Program Studi Matematika STKIP Siliwangi Bandung. 3(1). 33-58.

Rahmawati, I. N., Syafryadin, S., \& Widiastuti, R. (2019). Teaching narrative writing using freaky fables game: An Experimentation. English Education: Jurnal Tadris Bahasa Inggris, 12(2), 147-155.

Roestiyah. (2008). Strategi belajar mengajar. Jakarta: Rieneka Cipta

Sugiyono. (2011). Metode penelitian kuantitatif kualitatif dan $R \& D$. Bandung: Penerbit Alfabeta

Tarigan, H.G. (2013). Menulis sebagai suatu keterampilan berbahasa. Bandung: Angkasa.

Utami, A, K (2018). Pengaruh keterampilan mengajar guru terhadap prestasi belajar siswa pada mata pelajaran akuntansi di kelas XII IPS MAN 4 Bantul dengan motivasi belajar sebagai variabel intervening. S1 thesis, Fakultas Ekonomi UNY. 
Jadila: Journal of Development and Innovation

E-ISSN: 2723-6900

in Language and Literature Education

Volume 1 Number 22020

Publisher: Yayasan Karinosseff Muda Indonesia

Page : $150-160$

https://eprints.uny.ac.id/55738/ di akses tanggal 15 September 2019.

Wibowo, Y., Syafrizal, S., \& Syafryadin, S. (2020). An analysis of english teachers' strategies in teaching reading comprehension. JALL (Journal of Applied Linguistics and Literacy), 4(1), 20-27. 